\title{
Supporting Information for \\ Degradation of Drinking Water Disinfection Byproducts by Synthetic Goethite and Magnetite
}

\author{
Chan Lan Chun, Raymond M. Hozalski, and William A. Arnold \\ Department of Civil Engineering, University of Minnesota, 500 Pillsbury Dr. SE, Minneapolis, \\ Minnesota 55455-0116
}

Section S1. Chemical purity and supplier information

Page

Section S2. Iron mineral synthesis and XRD patterns

S1

Section S3. Reactor setup and sampling

Section S4. Analytical Methods

S3

Section S5. Kinetic modeling

S3

Section S6. Computation of one-electron reduction potentials

S4

Section S6. Computation of one-electron reduction potentials

S5

Figure S1. X-ray diffraction patterns of (a) magnetite and (b) goethite $\quad$ S2

Figure S2. TCAN hydrolysis as a function of $\mathrm{pH} \quad$ S5

Figure S3. Sorption isotherm of 1,1,1-TCP onto goethite and magnetite S6

$\begin{array}{ll}\text { Figure S4. Correlation between } \mathrm{E}_{\mathrm{H}}^{1} \text { and } \mathrm{X}_{\mathrm{g}} & \mathrm{S} 7\end{array}$

$\begin{array}{ll}\text { References } & \text { S8 }\end{array}$ 
Section S1. Chemical purity and supplier information

The following chemicals were purchased from Sigma-Aldrich and used as received: TCNM (99.6\%), TCAN (98\%), dichloroacetonitrile (DCAN; 98\%), trichloroacetamide (TCAM; 99\%), 1,1,1-TCP (Library product), 1,1-dichloropropanone (1,1-DCP; 98\%), TCM (99.9\%), TCAh (99 $\%$ ), TCAA (99\%), and nitromethane (NM; 99.34\%). Dichloronitromethane (DCNM; 95.13\%) and chloronitromethane (CNM; 92.89\%) were obtained from CanSyn Chemical Corporation and dichloroacetaldehyde hydrate (DCAh) $(96 \%)$ was purchased from TCI America. Reagent grade methanol, pentane, and methyl tertiary butyl ether (MTBE) were obtained from Fisher. 3morpholinopropanesulfonic acid (MOPS; 99.5\%, Sigma) buffer was adjusted to $\mathrm{pH} 7.5$ with $5 \mathrm{M}$ $\mathrm{NaOH}(97 \%$, Aldrich) and then was deoxygenated by argon sparging. Ultra-high purity Argon was obtained from TriState Airgas, and was purified using an in-line molecular sieve and oxygen traps. For capillary electrophoresis analysis, sodium phosphate dibasic (98+\%, EM Science), sodium phosphate monobasic ( $99.4 \%$, Fisher), hexadimethrine bromide (100\%, Aldrich), sodium acetate trihydrate (100\%, Fisher), sodium bromide (100\%, Fisher), sodium chloride $(100 \%$, Mallinckrodt Baker Inc.), and tetradecyltrimethylammonium bromide ( $99 \%$, Sigma) were used. $\mathrm{FeCl}_{2}$ (98\%, Aldrich), $\mathrm{FeCl}_{3} \cdot 6 \mathrm{H}_{2} \mathrm{O}$ (99\%, Fisher), $\mathrm{FeSO}_{4} \cdot 7 \mathrm{H}_{2} \mathrm{O}$ (101\%, Fisher), and $\mathrm{Fe}\left(\mathrm{NO}_{3}\right)_{3} \cdot 9 \mathrm{H}_{2} \mathrm{O}\left(98.7 \%\right.$, Fisher) were used to prepare $\mathrm{st}^{\circ} \mathrm{Ck}$ solutions of $\mathrm{Fe}(\mathrm{II})$ and to synthesize iron minerals. FerroZine (97\%, Aldrich), hydroxylamine hydr ${ }^{\circ} \mathrm{Chloride}(99 \%$, Aldrich), ammonium hydroxide ( $29.7 \%$ solution, Mallinckrodt), hydr ${ }^{\circ} \mathrm{Chloric}$ acid (37.4\%, Mallinckrodt), and ammonium acetate (98\%, Mallinckrodt) were used for quantification of ferrous iron. All aqueous solutions were prepared with ultrapure water (Milli-Q, Millipore).

Section S2. Iron mineral synthesis

Goethite $(\alpha-\mathrm{FeOOH})$, and magnetite $\left(\mathrm{Fe}_{3} \mathrm{O}_{4}\right)$ were synthesized in an anaerobic chamber $(93 \%$ $\mathrm{N}_{2} / 7 \% \mathrm{H}_{2}$, Coy Laboratory Products). Briefly, goethite was prepared by hydrolysis of $\mathrm{Fe}\left(\mathrm{NO}_{3}\right)_{3}$ in $\mathrm{pH} 12-13$ solution and crystallized at $70{ }^{\circ} \mathrm{C}$ for $70-80 \mathrm{~h}(1)$. Goethite was washed via dialysis (Spectra/Por, MWCO 5000) until conductivity of the wash solution was near zero and then freeze-dried. Magnetite was directly precipitated from mixed $\mathrm{FeCl}_{2} / \mathrm{FeCl}_{3}$ solutions at $\mathrm{pH} 8$ using the method similar to that described by Chun and Park (2). Magnetite was washed with oxygenfree and carbon dioxide-free Milli-Q water and stored as aqueous slurry in the anaerobic chamber. 
(a)

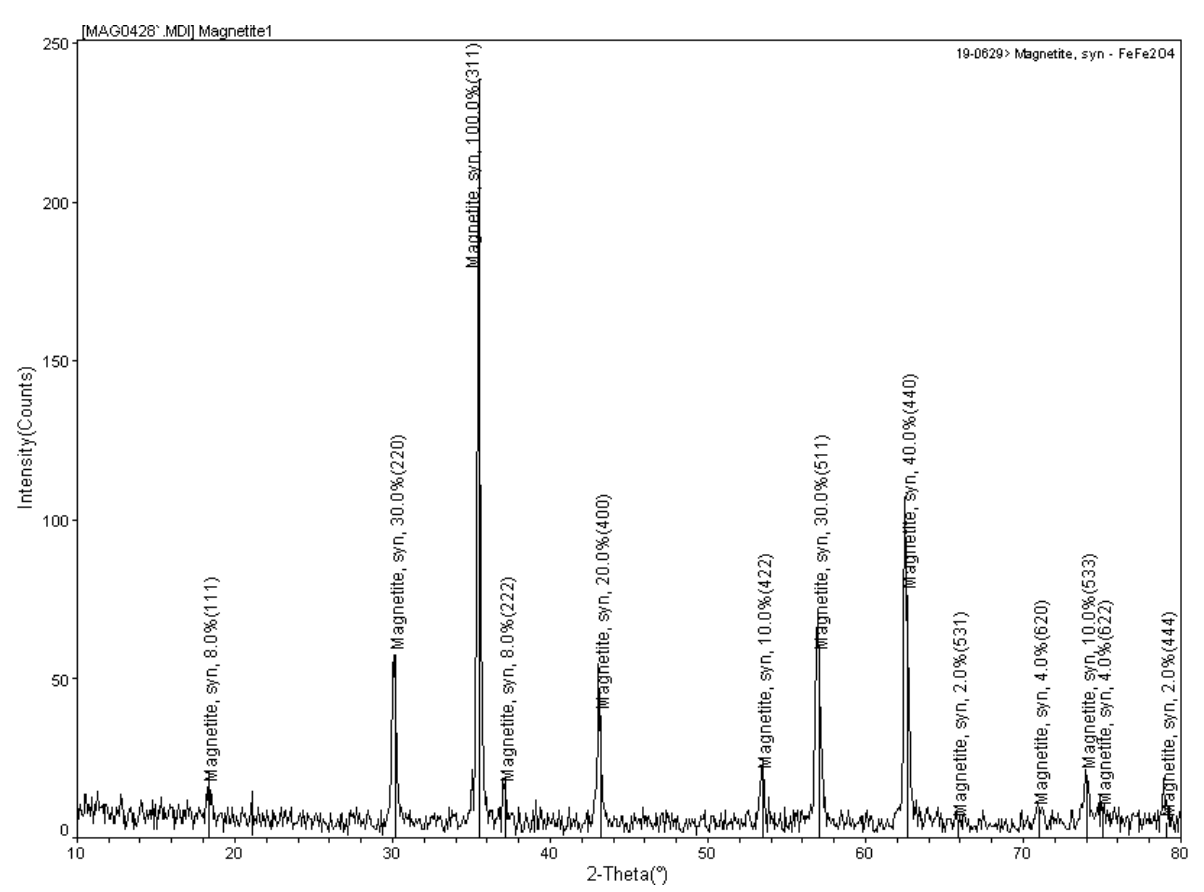

(b)

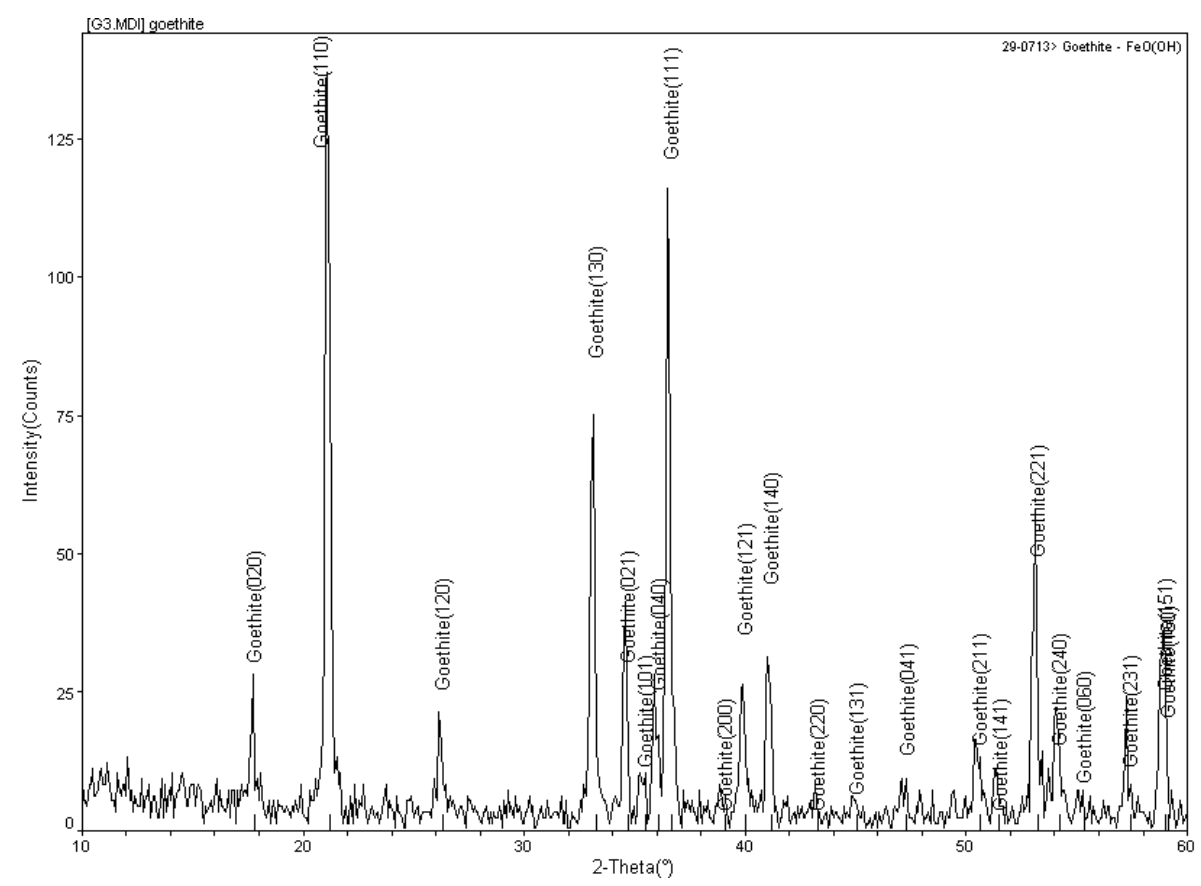

Figure S1. X-ray diffraction patterns of (a) magnetite and (b) goethite. 
Section S3. Reactor setup and sampling

Batch experiments were carried out in $123 \mathrm{~mL}$ serum bottles containing a $0.8 \mathrm{~g} / \mathrm{L}$ mineral suspension buffered at $\mathrm{pH} 7.5$ with deoxygenated $25 \mathrm{mM}$ morpholinopropanesulfonic acid (MOPS). Aliquots of $1 \mathrm{M} \mathrm{FeSO}_{4} \mathrm{St}^{\circ} \mathrm{Ck}$ solution, which was prepared by a modified $\mathrm{pr}^{\circ} \mathrm{Cedure}$ of Klausen et al.(3), were added to the reactors to achieve a total Fe(II) concentration of $1 \mathrm{mM}$. Each reactor was capped with a PTFE-lined septa and an aluminum crimp cap without headspace. Reactors were allowed to equilibrate after the addition of aqueous Fe(II) for a minimum $12 \mathrm{~h}$. The amount of sorbed Fe(II) was measured by the modified Ferrozine method described by Lin and Kester(4). Under such conditions, the respective amounts of sorbed Fe(II) onto goethite and magnetite are $6.3 \%$ and $14.6 \%$ of the total $\mathrm{Fe}(\mathrm{II})$ concentration. The preparation of reactors was conducted in an anaerobic chamber to prevent oxidation of aqueous $\mathrm{Fe}(\mathrm{II})$. After preparation, the reactors were removed from the anaerobic chamber and wrapped with aluminum foil to prevent potential photolysis reactions. Kinetic experiments were initiated by injecting the target DBP dissolved in methanol or methyl tert-butylether (MTBE). The initial DBP concentrations, which ranged from 10 to $150 \mu \mathrm{M}$, were 10- to 100 -fold greater than those typically found in distribution systems. The reactors were mixed about their longitudinal axes on a rotator (Glas-Col) at a speed of $50 \mathrm{rpm}$ at room temperature $\left(20 \pm 1{ }^{\circ} \mathrm{C}\right)$. Control experiments were also performed in a similar manner but without the mineral, without aqueous Fe(II), and without both (i.e. buffer only) to account for reaction with aqueous Fe(II), sorption/reaction with mineral, and hydrolysis, respectively. Aqueous samples were withdrawn at selected intervals using a two-syringe technique involving simultaneous injection of deoxygenated MOPS buffer to avoid the introduction of headspace. The aqueous samples were filtered though $0.2 \mu \mathrm{m}$ PTFE Gelman Acrodisk syringe tip filter to stop the reaction and to remove iron mineral particles.

Section S4. Analytical Methods

With the exceptions of trichloroacetic acid and nitromethane, all species were detected and quantified via on-column injection of a $1 \mu \mathrm{L}$ sample of the MTBE or n-pentane extract by an AS2000 liquid autosampler (ThermoQuest) onto a DB-1 column $(30 \mathrm{~m} \times 0.32 \mathrm{~mm}$ i.d. $\times 5 \mu \mathrm{m}$ film thickness, J\&W Scientific). The temperature of the electron capture detector was 290 or 300 ${ }^{\circ} \mathrm{C}$. Details for individual compounds classes are given below.

\section{Halonitromethanes}

The oven temperature was initially held at $40{ }^{\circ} \mathrm{C}$ for 5 minutes. This was followed by a 10 ${ }^{\circ} \mathrm{C} /$ minute temperature ramp to $180^{\circ} \mathrm{C}$ and then a $20^{\circ} \mathrm{C} /$ minute temperature increase to $240^{\circ} \mathrm{C}$. The temperature was then maintained at $240^{\circ} \mathrm{C}$ for 0.5 minutes.

\section{Haloacetonitriles and Haloacetamides}

The oven temperature was initially held at $40{ }^{\circ} \mathrm{C}$ for 0.5 minutes. This was followed by a 5.0 ${ }^{\circ} \mathrm{C} /$ minute temperature ramp to $70{ }^{\circ} \mathrm{C}$ where it was held for 15 minutes. The temperature was then increased $25^{\circ} \mathrm{C} /$ minute to $240^{\circ} \mathrm{C}$. The temperature was then maintained at $240^{\circ} \mathrm{C}$ for 6 minutes. 


\section{Haloketones and Halomethanes}

The oven temperature was initially held at $39^{\circ} \mathrm{C}$ for 3 minutes. This was followed by a 6.0 ${ }^{\circ} \mathrm{C}$ /minute temperature ramp to $70^{\circ} \mathrm{C}$ and an $8{ }^{\circ} \mathrm{C} /$ minute temperature increase to $148^{\circ} \mathrm{C}$ where the temperature was maintained for 5 minutes. The temperature was then increased 3.0 ${ }^{\circ} \mathrm{C} /$ minute to $240{ }^{\circ} \mathrm{C}$. The temperature was held at $240{ }^{\circ} \mathrm{C}$ for 2 minutes.

\section{Haloacetaldehydes}

The oven temperature was initially held at $35^{\circ} \mathrm{C}$ for 5 minutes. This was followed by a 2.0 ${ }^{\circ} \mathrm{C} /$ minute temperature ramp to $40^{\circ} \mathrm{C}$ where it was then held for 2 minutes. The temperature was then increased at $5{ }^{\circ} \mathrm{C} /$ minute to $120^{\circ} \mathrm{C}$ and the $25^{\circ} \mathrm{C} /$ minute to $240{ }^{\circ} \mathrm{C}$. The temperature was then maintained at $240{ }^{\circ} \mathrm{C}$ for 2 minutes.

Section S5. Kinetic Modeling

Reaction kinetics were fit using a pseudo-first-order reaction model:

$$
\begin{aligned}
& \frac{d C}{d t}=-k_{o} C=-\left(k_{r}+k_{h}\right) C \\
& \frac{d R}{d t}=k_{r} C \\
& \frac{d H}{d t}=k_{h} C
\end{aligned}
$$

where $\mathrm{C}=$ concentration of the parent $\mathrm{DBP}, \mathrm{R}=$ concentration of product produced via reductive dehalogentation, $\mathrm{H}=$ concentration of product produced via hydrolysis, $\mathrm{k}_{\mathrm{o}}=$ overall pseudo-firstorder rate constant, $\mathrm{k}_{\mathrm{r}}=$ reductive dehalogenation rate constant, $\mathrm{k}_{\mathrm{h}}=$ hydrolysis rate constant, and $\mathrm{t}=$ reaction time. In some cases (e.g., TCAh), an additional rate constant was used to account for undetected products. For TCNM, only the disappearance of the parent compound was modeled. 
Section S6. Computation of one-electron reduction potentials

One electron reduction potentials for the dehalogenation half reactions $\left(\mathrm{E}_{\mathrm{H}}^{1}\right)$ were determined via free energies computed using the Gaussian 03 electronic structure program suite (5). Details are provided in the Supporting Information. First, the gas-phase geometry of each parent molecule $\left(\mathrm{CCl}_{3}-\mathrm{R}\right)$, the radical species with one chlorine atom removed $\left(\mathrm{CCl}_{2}-\mathrm{R}^{\circ}\right)$, and the chloride ion were determined using density functional theory (B3LYP; 6). Frequency calculations were then carried out to verify that the calculated geometries were minima. Both of these calculations used the augmented correlation-consistent valence triple- $\xi$ basis set of Dunning (aug-cc-pVTZ; 7-9). The gas phase free energy was then computed using the G3MP2 method (10). The gas phase energies were then corrected to change from a $1 \mathrm{~atm}$ to a $1 \mathrm{M}$ standard state. Standard state solvation free energies in water were then calculated for the gas-phase optimized geometries using the Minnesota Gaussian Solvation Model (11) using the parameters described previously (12). The absolute free energy in solution was then computed by adding the gas-phase free energy to the standard-state free energy of solvation. The absolute free energies of reaction were then determined by subtracting the solvated free energies of the products from those of the reactants. The free energy of reaction was then referenced to the normal hydrogen electrode by subtracting $4.36 \mathrm{eV}$, and an additional correction was made to reference the energy values to a chloride concentration of $1 \mathrm{mM}$. Free energies were then converted to reduction potentials using Faraday's constant.

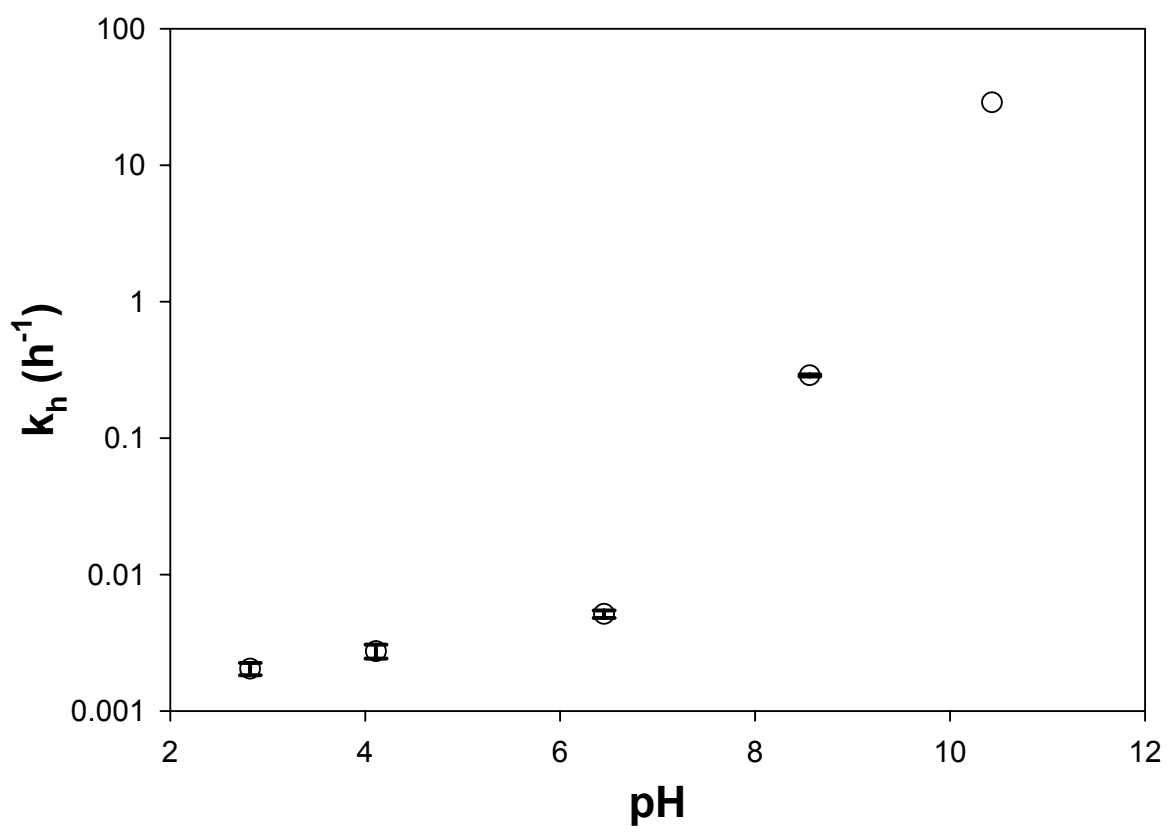

Figure S2. Hydrolysis of TCAN as a function of $\mathrm{pH}$. Error bars are $95 \%$ confidence intervals. 


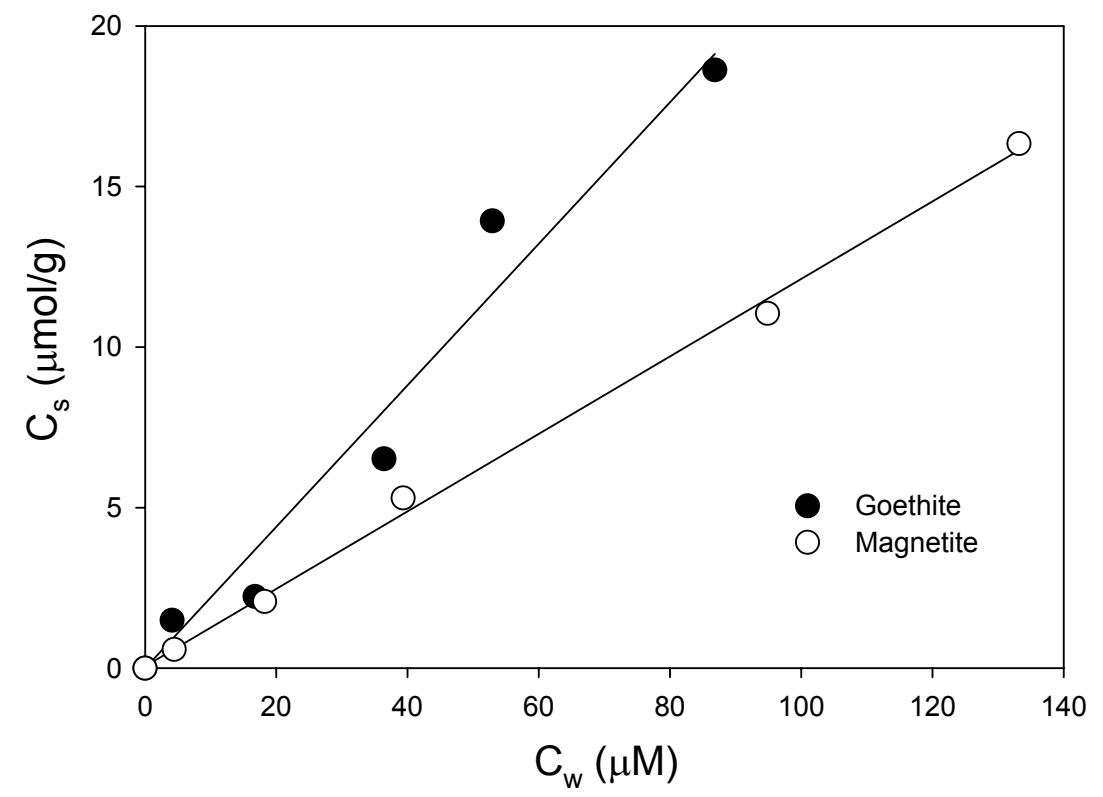

Figure S3. Sorption Isotherm of 1,1,1-TCP onto goethite $(\mathbf{O})$ and magnetite $(O) . \mathrm{C}_{\mathrm{w}}$ is the equilibrated aqueous concentration of 1,1,1-TCP and $\mathrm{C}_{\mathrm{s}}$ is sorbed concentration calculated by difference. Apparent iron mineral-water distribution coefficients $\left(\mathrm{K}_{\mathrm{d}}\right)$ are obtained by linear regression (solid lines). For goethite, $\mathrm{K}_{\mathrm{d}}$ is $0.22 \mathrm{~L} / \mathrm{g}\left(\mathrm{r}^{2}=0.95\right)$; for magnetite, $\mathrm{K}_{\mathrm{d}}$ is $0.12 \mathrm{~L} / \mathrm{g}\left(\mathrm{r}^{2}=\right.$ $0.99)$. 


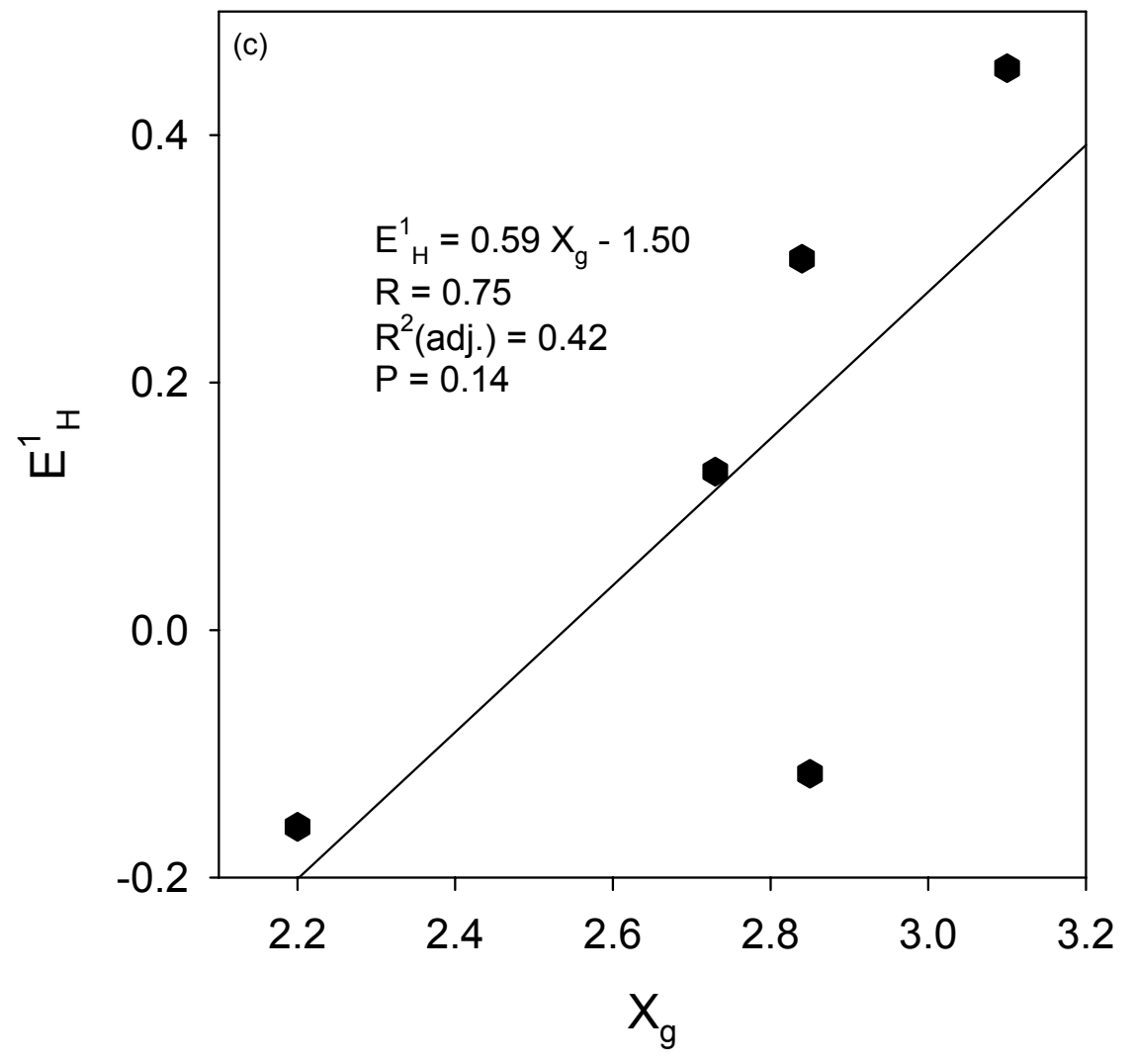

Figure S4. The correlation of $E_{H}^{1}$ with $X_{g}$ used to extrapolate an $E_{H}^{1}$ value for TCNM. $X_{g}$ has been used to develop correlations with a variety of physical and chemical properties (13). 


\section{References}

(1) Cornell, R. M.; Schwertmann, U. The Iron Oxides - Structure, Properties, Reactions, ${ }^{\circ}$ Ccurrence and Uses; VCH: New York, 1996.

(2) Chun, C.-L.; Park, J.-W. Oil spill remediation using magnetic separation. J. Environ. Eng. (Reston, VA) 2001, 127, 443-449

(3) Klausen, J.; Troeber, S. P.; Haderlein, S. B.; Schwarzenbach, R. P. Reduction of substituted nitrobenzenes by $\mathrm{Fe}(\mathrm{II})$ in aqueous mineral suspensions. Environ. Sci. Technol. 1995, 29, 2396-2404

(4) Lin, J.; Kester, D. R. The kinetics of iron(II) complexation by Ferrozine in seawater. Mar. Chem. 1992, 38, 283-301

(5) Frisch, M. J.; Trucks, G. W.; Schlegel, H. B.; Scuseria, G. E.; Robb, M. A.; Cheeseman, J. R.; Montgomery, J., J. A.; Vreven, T.; Kudin, K. N.; Burant, J. C.; Millam, J. M.; Iyengar, S. S.; Tomasi, J.; Barone, V.; Mennucci, B.; Cossi, M.; Scalmani, G.; Rega, N.; Petersson, G. A.; Nakatsuji, H.; Hada, M.; Ehara, M.; Toyota, K.; Fukuda, R.; Hasegawa, J.; Ishida, M.; Nakajima, T.; Honda, Y.; Kitao, O.; Nakai, H.; Klene, M.; Li, X.; Knox, J. E.; Hratchian, H. P.; Cross, J. B.; Bakken, V.; Adamo, C.; Jaramillo, J.; Gomperts, R.; Stratmann, R. E.; Yazyev, O.; Austin, A. J.; Cammi, R.; Pomelli, C.; ${ }^{\circ}$ Chterski, J. W.; Ayala, P. Y.; Morokuma, K.; Voth, G. A.; Salvador, P.; Dannenberg, J. J.; Zakrzewski, V. G.; Dapprich, S. D., A. D.; Strain, M. C.; Farkas, O.; Malick, D. K.; Rabuck, A. D.; Raghavachari, K.; Foresman, J. B.; Ortiz, J. V.; Cui, Q.; Baboul, A. G.; Clifford, S.; Cioslowski, J.; Stefanov, B. B.; Liu, G.; Liashenko, A.; Piskorz, P.; Komaromi, I.; Martin, R. L.; Fox, D. J.; Keith, T.; Al-Laham, M. A.; Peng, C. Y.; Nanayakkara, A.; Challacombe, M.; Gill, P. M. W.; Johnson, B.; Chen, W.; Wong, M. W.; Gonzalez, C.; Pople, J. A. Gaussian 03 (Revision B.01); Gaussian, Inc.: Wallingford, CT, 2004.

(6) Stephens, P. J.; Devlin, F. J.; Chabalowski, C. F.; Frisch, M. J. Ab Initio Calculation of vibrational absorption and circular dichroism spectra using density functional force fields. J. Phys. Chem. 1994, 98, 11623-11627

(7) Dunning, T. H. Gaussian basis sets for use in correlated molecular calculations I. The atoms boron through neon and hydrogen. J. Chem. Phys. 1989, 90, 1007-1023

(8) Kendall, R. A.; Dunning, T. H.; Harrison, R. J. aug-cc-pVDZ for first row. J. Chem. Phys. 1992, 96, 6796-6806

(9) Woon, D. E.; Dunning, T. H. Gaussian basis sets for use in correlated molecular calculations III. The atoms aluminum through argon. J. Chem. Phys. 1993, 98, 1358-1371

(10) Curtiss, L. A.; Redfern, P. C.; Raghavachari, K.; Rassolov, V.; Pople, J. A. Gaussian-3 theory using reduced Møller-Plesset order. J. Chem. Phys. 1999, 110, 4703-4709

(11) Xidos, J. D.; Li, J.; Thompson, J. D.; Hawkins, G. D.; Winget, P. D.; Zhu, T.; Rinaldi, D.; Liotard, D. A.; Cramer, C. J.; Truhlar, D. G.; Frisch, M. J. $M N-G S M$, version 3.1. Univeristy of Minnesota, Minneapolis, MN 55455-0431 2003

(12) Arnold, W. A.; Winget, P.; Cramer, C. J. Reductive dechlorination of 1,1,2,2tetrachloroethane. Environ. Sci. Technol. 2002, 36, 3536-3541

(13) Boyd, R. J.; Edgecombe, K. E. Atomic and group electronegativities from the electrondensity distributions of molecules. J. Am. Chem. $S^{\circ}$ C. 1988, 110, 4182-4186. 